\title{
PEMANFATAN MEDIA SLIDE POWERPOINT DALAM MENINGKATKAN PRESTASI BELAJAR SISWA SEKOLAH DASAR PADA PEMBELAJARAN TEMATIK
}

\author{
A. Jauhar Fuad \\ Institut Agama Islam Tribakti Kediri \\ info.ajauharfuad@gmail.com \\ Ananda Dwi Permatasari \\ Sekolah Dasar Nengeri Sanan 1 Nganjuk \\ anandapermata1@gmail.com
}

\begin{abstract}
The purpose of this study was to improve the quality of learning and learning achievement of grade IV students in my Heroes' Theme using PowerPoint slide media. This research was conducted in two cycles. Where in each cycle has stages that start from doing planning, action, observation and reflection. The results of the study: (1) through the application of PowerPoint slide media can improve the quality of learning; (2) the use of PowerPoint slide media can improve learning achievement 'pahlawanku' Theme in grade IV of SDN Sanan 1. The average value of the class before being subjected to action is 62 , in cycle 1 it increases to 71 and in cycle II to 80 . The number of students completing study at pre-action as many as 5 students or equal to $35.7 \%$, in the first cycle increased to 9 students or equal to $64.3 \%$, and in the second cycle to 12 students or by $85.7 \%$. The advice given is that the teacher should use innovative models and varied media in learning.
\end{abstract}

\begin{abstract}
Abstrak:
Artikel ini menjelaskan peningkatkan kualitas pembelajaran dan prestasi belajar siswa kelas IV pada Tema Pahlawanku dengan menggunakan media slide PowerPoint. Pemecahan masalah dengan penelitian tindakan kelas dengan dua siklus. Pada setiap siklus memiliki tahapan yang dimulai dari melakukan perencanaan, tindakan, observasi dan refleksi. Penelitian dapat disimpulkan: (1) melalui penerapan media slide PowerPoint dapat meningkatkan kualitas proses pembelajaran; (2) dengan menggunakan media slide PowerPoint prestasi belajar siswa meningkat pada Tema Pahlawanku. Nilai rata-rata kelas meningkat dari siklus ke siklus II, demikian juga denga jumlah siswa yang tuntas belajar dari siklus ke siklus II mengalami peningkatan.
\end{abstract}


Kata Kunci: Prestasi Belajar, Pahlawan Dan Media Slide Powerpoint

\section{Pendahuluan}

Hasil evaluasi awal bahwa pretsasi belajar siswa kelas IV SDN Sanan 1 pada evaluasi Tema 5 Subtema 1 didapat rata-rata 6,2 dengan ketuntasan $35.7 \%$. Kondisi ini menunjukkan bahwa tingkat pemahaman siswa pada tema tersebut masih rendah sehingga menyebabkan prestasi belajar yang rendah. Siswa perlu belajar dengan menggunakan media pembelajaran sehingga dapat meningkatkan motivasi belajar dan prestrasi belajar.

Permasalahan di atas membutuhkan usaha pemecahan masalah agar siswa termotivasi dalam proses pembelajaran dan tujuan pembelajaran tercapai sehingga prestasi belajar siswa meningkat. Maka untuk mengatasi permaslahan tersebut di atas menggunakan media pembelajaran yang dapat menarik minat belajar siswa sehingga siswa terangsang dalam melakukan proses pembelajaran.

Ada tiga fitur yang menjadi kekhasan media dalam proses belajar mengajar, yaitu bahwa media memiliki kemampuan untuk menangkap, menyimpan dan menampilkan suatu benda atau peristiwa, media memiliki kemampuan untuk menampilkan kembali benda atau peristiwa dalam berbagai cara sesuai dengan kebutuhan, dan media memiliki kemampuan untuk menampilkan suatu objek atau peristiwa yang mengandung makna (Fuad 2010). Fungsi media pembelajaran sangat penting untuk digunakan sebagai bentuk upaya dalam meningkatkan proses pembelajaran sehingga menjadi pembelajaran yang efektif dan fungsional.

Media yang perlu digunakan adalah media yang memfasilitasi penyampaian informasi, dengan tampilan yang kreatif dan inovatif. Salah satunya adalah media slide PowerPoint. Dengan aplikasi PowerPoint ini dapat memudahkan proses pembelajaran dan meningkatkan kualitas dan prestasi belajar(Badri and Riasti 2011). Media pembelajaran Powerpoint dipilih dalam penelitian ini untuk memfasilitasi siswa dalam menganalisis masalah yang disajikan (Murtikusuma 2015).

Penelitian menyimpulkan ada perbedaan peningkatan pengetahuan antara menggunakan media powerpoint dan flip chart, penggunaan powerpoint lebih baik (Nurhidayat 2012). Media Powerpoint dapat mendorong 
Oleh: A. Jauhar Fuad \& Ananda Dwi Permatasari

semangat siswa dalam belajar (Burton 2004). Penelitian lain, menyimpulkan bahwa penggunaan media slide Powerpoint IPA terbukti memiliki kontribusi terhadap minat dan prestasi belajar (Elpira and Ghufron 2015).

PowerPoint dapat bermanfaat, tetapi materi yang tidak berkaitan dengan presentasi dapat berbahaya bagi pembelajaran siswa (Bartsch and Cobern 2003, 77). PowerPoint dan multimedia cocok dalam pembelajaran dan pemrosesan informasi (Penciner 2013). Slide PowerPoint dan handout lebih meningkatkan pengalaman belajar siswa(Apperson, Laws, and Scepansky 2008), dengan menerapkan model pembelajaran kuantum yang dibantu oleh media Microsoft Powerpoint dalam pembelajaran sains di kelas IV prestasi belajar dapat meningkat (Sukarsa, Dantes, and Arini 2014). Powerpoint akan lebih menarik bagi siswa karena dirancang dengan grafik dan animasi yang bagus. Penggunaan powerpoint efektif untuk digunakan dalam proses pembelajaran. Hal ini dapat dilihat dari indikator yang menunjukkan bahwa ada peningkatan prestasi belajar siswa (Nurlatifah 2015)..

Maka perbaikan pembelajaran yang dinunakan dengan menggunakan media slide
PowerPoint pada pembelajaran Tema Pahlawanku di Kelas IV SDN Sanan 1. Artikel mengulas tetang proses pembelajaran dan prestasi belajar pada Tema Pahlawanku dengan memanfatakan media slide Powerpoint.

\section{Pembelajaran Tematik}

Proses

pembelajaran diharapkan berlangsung secara menarik, sehingga akan memusatkan perhatian siswa, merasa bahagia, dan memfasilitasi siswa untuk berpartisipasi dalam pembelajaran, dan menggunakannya untuk siswa mereka. Kondisi pembelajaran dapat dibuat dengan pendekatan pembelajaran tematik. Pembelajaran tematik memiliki karakteristik yang berpusat pada siswa, memberikan pengalaman langsung kepada siswa, pembagian mata pelajaran tidak terlalu jelas, menyajikan konsep dari berbagai mata pelajaran dalam proses pembelajaran, fleksibel, prestasi belajar dapat berkembang sesuai dengan minat dan kebutuhan siswa(Sungkono

2006).Pembelajaran tematik diterapkan pada pendidikan dasar dengan membentuk tema dengan menghubungkan antar mata pelajaran (Prastowo 2017, 13).

$$
\text { Langkah-langkah dalam }
$$

menerapkan pembelajaran tematik meliputi perencanaan, evaluasi. 
Oleh: A. Jauhar Fuad \& Ananda Dwi Permatasari

Implementasi pembelajaran tematik, yang disediakan oleh sekolah akan memberikan manfaat seperti siswa yang lebih menyenangkan karena resistensi terhadap minat dan kebutuhan siswa, pengalaman dan kegiatan pembelajaran yang relevan dengan tingkat perkembangan dan kebutuhan siswa, pembelajaran prestasi akan bertahan lebih lama dan bermakna, dan menumbuhkan keterampilan sosial, seperti kerja sama, toleransi, komitmen, dan responsif terhadap ide orang lain. Namun pembelajaran ini masih kurang sehingga tidak semua guru mampu mengintegrasikan kurikulum dengan konsep-konsep yang ada pada subjek dengan benar.

Pada umumnya guru sekolah dasar memiliki kesiapan dalam pembelajaran tematik (Wangid et al. 2014; Kristiantari 2015). Pembelajaran tematik akan lebih menarik jika dikaitkan dengan kearifan lokal akan terhubung dengan siswa-siswa untuk bertindak dengan benar(Utari, Degeng, and Akbar 2016).

\section{Prestasi Belajar}

Prestasi itu adalah hasil yang telah dicapai (dari apa yang telah dilakukan, dilakukan, dll.) (Endarmoko 2007). Prestasi adalah bukti yang dapat dicapai oleh siswa dalam jangka waktu tertentu dan dapat diukur menggunakan alat atau tes dengan hasil berupa angka-angka sebagai deskripsi pencapaian belajar siswa. Dengan kata laian prestasi belajar adalah hasil belajar yang diperoleh siswa selama waktu tertentu dalam kegiatan belajar (Mulyani 2013).

Tolok ukur prestasi belajar mengacu pada pencapaian taksonomi Bloom, yang meliputi aspek kognitif, afektif, dan psikomotor (Siagian 2015). Aspek yang digunakan dalam tulisan ini lebih mengarah pada kemampuan kognitif. Hal ini dilakukan karena relative lebih mudah dalam aspek pengukurannya jika dibandingkan dengan aspek afektif dan psikomotorik.

Berdasarkan beberapa pendapat di atas, dapat disimpulkan bahwa prestasi belajar adalah tingkat pencapaian siswa dalam menguasai pengetahuan pada mata pelajaran di sekolah yang ditunjukkan dengan skor berupa angka (kuantitatif) yang diberikan oleh guru sebagai bukti keberhasilan belajar siswa ini. Maka prestasi belajar disini diwujudkan dalam bentuk angka dan pencapaian ketuntasn belajar minimum.

\section{Media Pembelajaran}

Media merupakan bentuk jamak dari kata "medium" yang berasal dari bahasa latin yang berarti 
"antara". Medium dapat didefinisikan sebagai perantara atau pengantar terjadinya komunikasi dari pengirim menuju penerima. Media adalah segala sesuatu yang dapat digunakan untuk menyalurkan pesan sehingga dapat merangsang siswa untuk belajar (Arsyad 2003, 3). Media juga dapat diartikan sebagai alat yang ada disekitar siswa yang dapat digunakan sebagai saluran pesan untuk mencapai tujuan pembelajaran (Djamarah 2002, 137). Media pembelajaran diklasifikasikan berdasarkan tujuan penggunaan dan karakteristik jenis media (Fuad 2010). Media pembelajaran terdiri dari empat jenis, yaitu (1) media dua dimensi misalnya; gambar, karikatur, poster, foto, diagram, dan poster, (2) media tiga dimensi dalam bentuk model, misalnya; spisemen, etalase, benda tiruan, aquariyum dan dan model pembangunan ruang angkasa, (3) media proyeksi seperti slide, LCD, strip film, film dan OHP (overhead proyektor), dan (4) lingkungan misalnya; lingkungan sekolah (taman, kebun dan lain-lain) dan
sebagainya(Sudjana and Rivai 2009, $3)$.

\section{Media PowerPoint}

Powerpoint adalah program aplikasi yang berfungsi untuk membuat presentasi dalam bentuk slide(Carmichael and Pawlina 2000). Powerpoint adalah program Microsoft yang dirancang khusus dalam presentasi, yang digunakan dalam semua bidang khususnya di dunia pendidikan, atau individu yang digunakan untuk menarik proses komunikasi yang menarik ${ }^{1}$. PowerPoint yang menarik karena ada beberapa tool yang dapat digunakan untuk memproses teks, warna, gambar, dan grafik dan animasi yang dapat diproses sesuai dengan kreativitas penggunanya (Stein 2006). Berdasarkan pemahaman di atas, disimpulkan bahwa Powerpoint adalah perangkat lunak yang mampu menampilkan program multimedia yang menarik dengan menampilkan berbagai elemen media seperti teks, suara, warna, titik, gambar, grafik, dan animasi yang dapat digunakan untuk keperluan presentasi.

https://doi.org/10.1080/15358590600763383 ; J. Holzl, "Twelve Tips for Effective PowerPoint Presentations for the Technologically Challenged," Medical Teacher 19, no. 3 (January 1, 1997): 175-79, https://doi.org/10.3109/01421599709019377
Assessment of Student Preferences for PowerPoint Presentation Structure in Undergraduate Courses"; David G. Levasseur and J. Kanan Sawyer, "Pedagogy Meets PowearPoint: A Research Review of the Effects of Computer-Generated Slides in the Classroom," The Review of Communication, August 19, 2006, el Bidayah: Journal of Islamic Elementary Education Volume 1, Nomor 1, Maret 2019 


\section{Metode Penelitian}

Penelitian ini menggunakan penelitian tindakan kelas yang merupakan tindakan reflektif oleh aktor untuk meningkatkan proses pembelajaran. Penelitian Tindakan Kelas adalah refleksi dari kegiatan belajar dalam bentuk tindakan, yang sengaja diangkat dan terjadi di kelas secara bersamaan. Tindakan diberikan oleh guru atau oleh arahan guru yang dibuat oleh siswa (Fuad and Hamam 2012; Fuad and Winarsih 2018). PTK dapat dikatakan berhasil jika siswa telah belajar banyak bukan berapa banyak guru bertindak. Model riset ini mencakup empat tahap tindakan yaitu perencanaan, tindakan, observasi dan refleksi.

Subjek penelitian ini adalah siswa kelas IV SD Negeri Sanan 1 tahun pelajaran 2018/2019, dengan jumlah 14 siswa, dengan rincian 8 siswa laki-laki dan 6 siswa perempuan. Penelitian ini berlangsung di Sekolah Dasar Negeri Sanan 1, dengan alamat Desa Sanan, Pace, Nganjuk. SDN Sanan 1.

Waktu dilaksanakannya penelitian ini adalah pada akhir bulan Oktober hingga bulan November semester 1 tahun pelajaran 2018/2019. Penelitian Pra Siklus dilaksanakan pada 22 Oktober 2018. Penelitian Siklus I dilaksanakan pada 25 Oktober 2018.
Dan penelitian Siklus II dilaksanakan pada 01 November 2018.

Data kuantitatif dalam bentuk prestasi belajar kognitif, dianalisis menggunakan teknik analisis deskriptif dengan menentukan rerata atau rerata. Data kuantitatif akan disajikan sebagai persentase. Data kualitatif disajikan dalam kalimat yang dipisahkan oleh kategori untuk mendapatkan kesimpulan. Data kualitatif ini diperoleh dari mengolah data yang diperoleh dari instrumen pengamatan aktivitas siswa atau instrumen pengamatan keterampilan guru.

\section{Hasil dan Pembahasan \\ Deskripsi Hasil Penelitian Perbaikan Pembelajaran \\ Pra Siklus}

Prestasi belajar yang diperoleh siswa kelas IV Sekolah Dasar Sanan 1 sebelum menggunakan media powerpoint pretasi belajar siswa masih sangat rendah. Ini bisa dilihat dari hasil tes yang diberikan sebelumnya. Derikut ini hasil analisis sebelum menggunagkan slaid powerpoint. 
Pemanfaatan Media Slide Power Point dalam Meningkatkan Prestasi Siswa...

Oleh: A. Jauhar Fuad \& Ananda Dwi Permatasari

Tabel 1. Prestasi Belajar Tema Pahlawanku Pra Siklus

\begin{tabular}{|c|c|c|c|c|c|}
\hline $\begin{array}{c}\text { Jml. } \\
\text { Sisw } \\
\mathbf{a}\end{array}$ & \multicolumn{2}{|c|}{$\begin{array}{c}\text { Ketuntasa } \\
\text { n }\end{array}$} & \multicolumn{2}{c|}{ Presentase } & Rata \\
\cline { 2 - 5 } & $\mathbf{T}$ & $\mathbf{B T}$ & $\mathbf{T}$ & $\mathbf{B T}$ & $\begin{array}{c}\text { rata } \\
\text { Kela } \\
\mathbf{s}\end{array}$ \\
\hline 14 & 5 & 9 & $35.7 \%$ & $64.3 \%$ & 62 \\
\hline \multicolumn{5}{|c|}{$\mathrm{KKM}=70$} \\
\hline
\end{tabular}

Berdasarkan tabel 1, dapat dilihat bahwa dari 14 siswa, hanya 5 siswa $(35,7 \%)$ yang berhasil mencapai ketuntasan belajar, sedangkan sisanya 9 siswa $(64,3 \%)$ belum berhasil mencapai ketuntasan belajar. Sedangkan rata-rata pretsai belajar siswa kelas IV 62 masih jauh di bawah KKM yang ditentukan, yaitu 70.

\section{Perbaikan Siklus I}

Implementasi Cycle 1 diadakan pada hari Kamis, 25 Oktober 2018. Pembelajaran berlangsung selama enam jam pelajaran (210 menit), membahas Tema Pahlawanku dengan Tema Pahlawan Perjuangan. Semua siswa hadir di pertemuan ini.

Pada kegiatan inti, guru menggunakan slide powerpont di layar dan menjelaskan tema pahlawanku, Tema Perjuangan Pahlawan. Slide ini dibuat semenarik mungkin dengan memperhatikan prinsip-prinsip pengembangan media powerpoint. Pada kesempatan itu, siswa terlihat antusias memperhatikan guru menampilkan slide

powerpoint.

Guru memperlihatkan gambar seorang anak yang menggambarkan sikap kepahlawanan dan meminta siswa untuk memberikan pendapat tentang gambar itu. Saat memberikan pendapat, hanya beberapa siswa yang berani mengungkapkan pendapatnya. Selanjutnya guru menyimpulkan sikap heroik yang tercermin dalam gambar dan memberi tahu siswa bahwa mereka akan belajar tentang nilai-nilai heroik para Raja di zaman Hindu, Budha dan Islam.

Guru memperlihatkan beberapa gambar contoh sikap heroik. Siswa berkelompok, berdiskusi jawaban untuk menjawab pertanyaan setelah mengamati gambar. Siswa yang mengalami kesulitan belajar menerima bimbingan dari guru, dengan cara guru mendekati siswa yang menunjuk jari dan perlu penjelasan. Ada satu kelompok yang mengalami kesulitan menyebutkan penggunaan panas dan sinar matahari dalam kehidupan seharihari. Diskusi selesai dilaksanakan, perwakilan dari masing-masing kelompok mempresentasikan hasil kerja kelompok mereka secara bergantian di depan kelas. Siswa lain yang tidak melakukan presentasi diberikan kesempatan untuk mengajukan pertanyaan dan kepada 
Pemanfaatan Media Slide Power Point dalam Meningkatkan Prestasi Siswa...

Oleh: A. Jauhar Fuad \& Ananda Dwi Permatasari

kelompok yang sedang melakukan presentasi.

Kemudian siswa diminta untuk membaca teks pada Lembar Kerja Siswa. Setelah siswa membaca teks, siswa kemudian menjawab pertanyaan berdasarkan teks. Setelah selesai, guru mendiskusikan jawaban atas pertanyaan itu. Siswa dapat meningkatkan jawaban mereka jika perlu. Setelah itu siswa diminta menceritakan kembali isi bacaan. Guru menyampaikan rubrik penilaiannya kepada siswa.

Kemudian guru memberi contoh pemikiran dan nilai-nilai kepahlawanan yang bias mempengaruhi masyarakat. Guru menampilkan contoh sikap kepahlawanan yang ada di sekitar kita. Selanjutnya siswa diminta member contoh dengan menuliskan nilai perjuangan atau peninggalan pahlawan yang mempengaruhi masyarakat sekitar.

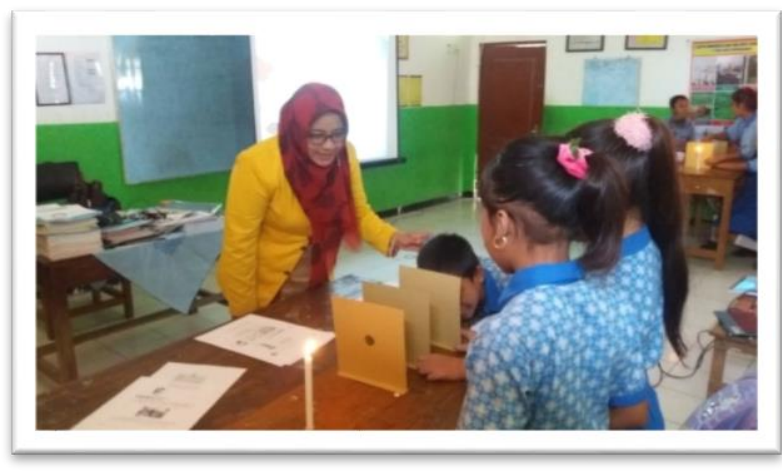
Gambar 1 Guru membantu siswa
melakukan pengamatan

Selanjutnya guru membaca dan membantu siswa memahami ilustrasi pada LKS mengenai sifat-sifat cahaya yang dipantulkan dalam air kolam. Kemudian guru menyiapkan alat dan bahan dalam percobaan sifat-sifat cahaya. Guru menampilkan perjanjian tentang percobaan sehingga percobaan berjalan dengan baik. Siswa berikutnya diminta untuk bereksperimen sesuai dengan slide yang ditunjukkan. Setiap siswa mencatat hasil percobaan yang dilakukan. Di akhir laporan, siswa diminta untuk menarik kesimpulan dan menyerahkan hasil laporan masing-masing kelompok di depan kelas.

Pengamatan pada tahap ini pembelajaran dilakukan menggunakan media powerpoint. Berdasarkan hasil pengamatan, guru secara keseluruhan telah melakukan pembelajaran dengan baik, hanya saja ketika memberikan materi pelajaran, penjelasannya terlalu cepat dan guru masih memberikan sedikit hadiah kepada siswa yang aktif bertanya atau aktif. Guru juga kurang memiliki penguatan dalam pekerjaan masing-masing siswa.

Dalam percobaan sifat-sifat cahaya, alat dan bahan tidak dibuat dalam kelompok, sehingga siswa berebut pada saat pengamatan dan menghasilkan hasil pengamatan yang kurang optimal. Berdasarkan pengamatan, prestasi belajar siswa baik tetapi kurang optimal dapat dilihat ketika guru memberikan 
kesempatan kepada siswa untuk mengajukan pertanyaan dan pendapat, hanya beberapa siswa yang berani mengangkat tangan. Terlihat siswa yang lebih pintar masih mendominasi dalam kelompoknya. Banyak siswa juga mengeluh bahwa mereka tidak dapat melihat secara untuh media yang ditampilkan, terutama siswa memilih duduk di tepi.

Prestasi belajar siswa yang diperoleh dari hasil evaluasi pada siklus I yang disajikan pada tabel 2 .

Tabel 2. Prestasi Belajar Tema Pahlawanku Siklus I

\begin{tabular}{|c|c|c|c|c|c|}
\hline \multirow{2}{*}{$\begin{array}{c}\text { Jml. } \\
\text { Sisw } \\
\text { a }\end{array}$} & \multicolumn{2}{|c|}{$\begin{array}{l}\text { Ketunta } \\
\text { san }\end{array}$} & \multicolumn{2}{|c|}{ Presentase } & \multirow{2}{*}{$\begin{array}{c}\text { Rata- } \\
\text { rata } \\
\text { Kela } \\
\mathbf{S}\end{array}$} \\
\hline & $T$ & BT & $T$ & BT & \\
\hline 14 & 9 & 5 & $\begin{array}{c}64.3 \\
\%\end{array}$ & $\begin{array}{c}35.7 \\
\%\end{array}$ & 71 \\
\hline \multicolumn{6}{|c|}{$\mathrm{KKM}=70$} \\
\hline
\end{tabular}

Berdasarkan tabel 2, didapat bahwa dari 14 siswa, 9 siswa $(64,3 \%)$ telah berhasil mencapai ketuntasan belajar dengan (nilai $\geq 70$ ), sedangkan 5 siswa $(35,7 \%)$ belum berhasil mencapai ketuntasan belajar (nilai < 70). Rata-rata pertasai belajar kelas 71, nilainya di atas KKM yang ditentukan yaitu 70 . Jumlah siswa yang mencapai (KKM $\geq 70$ ) kurang dari 75\%. Berdasarkan hasil refleksi pada siklus I, proses pembelajaran belum berjalan secara baik dan optimal, sehingga peneliti bersama rekan guru membahas perencanaan untuk melakukan tindak lanjut perbaikan dalam pembelajaran pada siklus II.

\section{Perbaikan Siklus II}

Implementasi dari siklus II diadakan pada hari Kamis 01 November 2018. Implementasi dari siklus II membahas tema pahlawanku, tema perjuangan Pahlawan.

Pada kegiatan inti, guru menampilkan slide powerpont di layar dan menjelaskan tema pahlawanku, Tema Perjuangan Pahlawan. Siswa terlihat bersemangat ketika guru menampilkan slide powerpoint yang dipancarkan melalui LCD. Guru memperlihatkan gambar seorang anak yang menggambarkan sikap kepahlawanan dan meminta siswa untuk memberikan pendapat tentang gambar itu. Saat memberikan pendapat, hanya beberapa siswa yang berani mengungkapkan pendapatnya. Selanjutnya guru menyimpulkan sikap heroik yang tercermin dalam gambar dan memberi tahu siswa bahwa mereka akan belajar tentang nilai-nilai heroik para Raja di zaman Hindu, Budha dan Islam.

Guru memperlihatkan beberapa gambar contoh sikap heroik. Siswa 
Pemanfaatan Media Slide Power Point dalam Meningkatkan Prestasi Siswa...

Oleh: A. Jauhar Fuad \& Ananda Dwi Permatasari

berkelompok, berdiskusi jawaban untuk menjawab pertanyaan setelah mengamati gambar. Kelompok tidak banyak mengalami kesulitan dalam pembelajaran. Dalam proses pembelajaran banyak siswa yang bertanya dan mengajukan pendapatnya, sehingga proses belajar berjalan dengan baik. Guru memberikan penguatan pada jawaban siswa. Guru juga memberikan kesempatan untuk mengomentari jawaban yang diberikan oleh siswa lain.

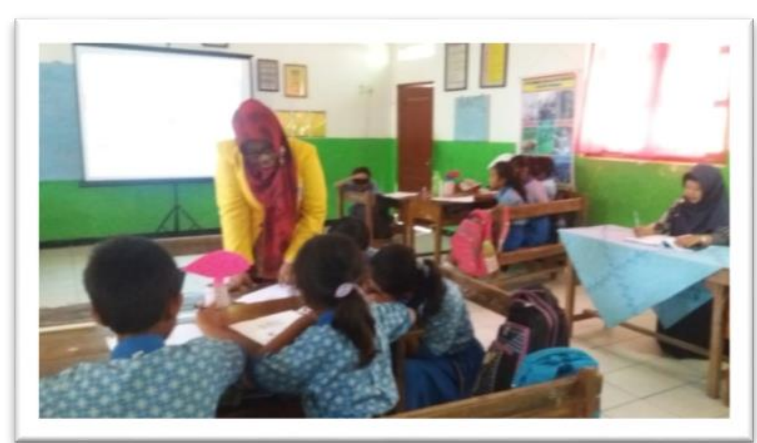

Gambar 2 Guru memberikan penguatan terhadap jawaban siswa

Kemudian siswa diminta untuk membaca teks pada Lembar Kerja Siswa. Setelah siswa membaca teks, siswa kemudian menjawab pertanyaan berdasarkan teks. Setelah selesai, guru mendiskusikan jawaban atas pertanyaan itu. Siswa dapat meningkatkan jawaban mereka jika perlu. Setelah itu siswa diminta menceritakan kembali isi bacaan. Guru menyampaikan rubrik penilaiannya kepada siswa.

Kemudian guru member contoh pemikiran dan nilai-nilai kepahlawanan yang bias mempengaruhi masyarakat. Guru menampilkan contoh sikap kepahlawanan yang ada di sekitar kita. Selanjutnya siswa diminta member contoh dengan menuliskan nilai perjuangan atau peninggalan pahlawan yang mempengaruhi masyarakat sekitar.

Selanjutnya guru membaca dan membantu siswa memahami ilustrasi pada LKS mengenai sifat-sifat cahaya yang dipantulkan dalam air kolam. Kemudian guru meminta siswa menyiapkan alat dan bahan untuk sifat cahaya eksperimental di setiap kelompok. Guru menampilkan perjanjian tentang percobaan sehingga percobaan berjalan dengan baik. Siswa berikutnya diminta untuk bereksperimen sesuai dengan slide yang ditunjukkan. Setiap siswa mencatat hasil percobaan yang dilakukan. Di akhir laporan, siswa diminta untuk menarik kesimpulan dan menyerahkan hasil laporan masing-masing kelompok di depan kelas.

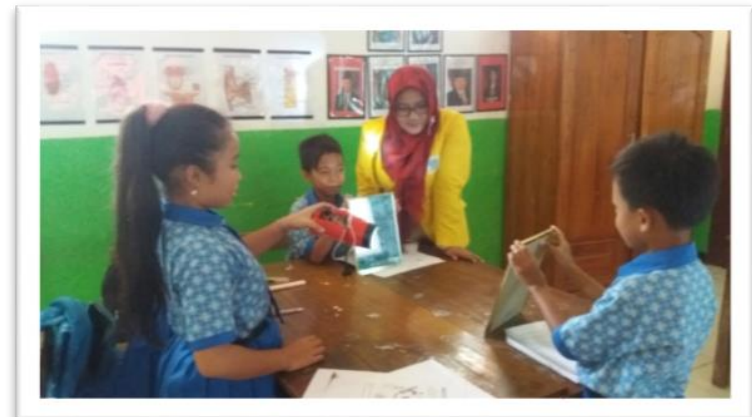

Gambar 3 Siswa melakukan percobaan dengan bimbingan guru 
Oleh: A. Jauhar Fuad \& Ananda Dwi Permatasari

Sebagai penutup, guru merangkum apa yang telah mereka pelajari hari ini. Kemudian siswa dan guru merefleksikan pembelajaran yang baru saja dilakukan dan terus memberikan pertanyaan evaluasi kepada siswa. Evaluasi digunakan untuk mengukur sejauh mana siswa menguasai materi yang telah dipelajari. Guru menutup pelajaran dengan berdoa bersama dan menyapa.

Berdasarkan hasil pengamatan pada siklus II, aktivitas guru banyak yang mengalami peningkatan dibandingkan siklus I. Pada siklus II guru memiliki kata-kata yang lebih teratur dan tidak terburu-buru saat menyampaikan materi pelajaran. Guru memberikan penguatan kepada siswa yang aktif sehingga siswa lebih semangat dalam pembelajaran. Guru juga sering memberikan penguatan dan umpan balik atas jawaban dan pendapat masing-masing siswa.

Hasil pengamatan siswa juga menunjukkan peningkatan. Hal ini dapat dilihat dari antusiasme siswa ketika menghadiri penelitian, karena Tema Pahlawanku dihadirkan dengan penampilan berupa gambar, suara dan animasi yang menarik melalui media powerpoint. Siswa mulai memberanikan bertanya, mereka sudah termotivasi dalam belajar karena ada dorongan. Mereka sudah memberanikan diri untuk berdiskusi menyanggah pendapat yang berbeda. Siswa yang pandai tidak lagi mendominasi, karena siswa telah dibagi dengan jelas. Prestasi belajar yang diperoleh dari hasil evaluasi pada siklus II mengalami peningkatan.

Tabel 3 Prestasi Belajar Tema Pahlawanku Siklus II

\begin{tabular}{|c|c|c|c|c|c|}
\hline $\begin{array}{c}\text { Jml. } \\
\text { Sis } \\
\text { wa }\end{array}$ & \multicolumn{2}{|c|}{$\begin{array}{c}\text { Ketunta } \\
\text { san }\end{array}$} & \multicolumn{2}{c|}{ Presentase } & $\begin{array}{c}\text { Rata- } \\
\text { rata } \\
\text { Kelas }\end{array}$ \\
\hline 14 & 12 & 2 & $\begin{array}{c}85.7 \\
\%\end{array}$ & $\begin{array}{c}14.3 \\
\%\end{array}$ & 80 \\
& \multicolumn{6}{|c|}{ KKM $=70$} \\
\hline
\end{tabular}

Berdasarkan tabel 3, didapat dilihat bahwa dari 14 siswa, sebanyak 12 siswa $(85,7 \%)$ telah berhasil mencapai ketuntasan belajar (nilai $\geq 70$ ), dan ada 2 siswa $(14,3 \%)$ belum berhasil mencapai ketuntasan belajar (nilai $<70$ ). Kelas rata-rata siswa di atas KKM yang ditentukan, yaitu 70 .

Media Powerpoint terbukti mampu meningkatkan proses pembelajaran dan prestasi belajar Tema Pahlawanku. Hal ini dapat dilihat dari proses belajaran dan hasil prestasi belajar Tema Pahlawanku pada siklus II dibandingkan dengan siklus I dan pra siklus. Berikut ini adalah tabel perbandingan pra siklus, siklus I dan siklus II. 
Pemanfaatan Media Slide Power Point dalam Meningkatkan Prestasi Siswa...

Oleh: A. Jauhar Fuad \& Ananda Dwi Permatasari

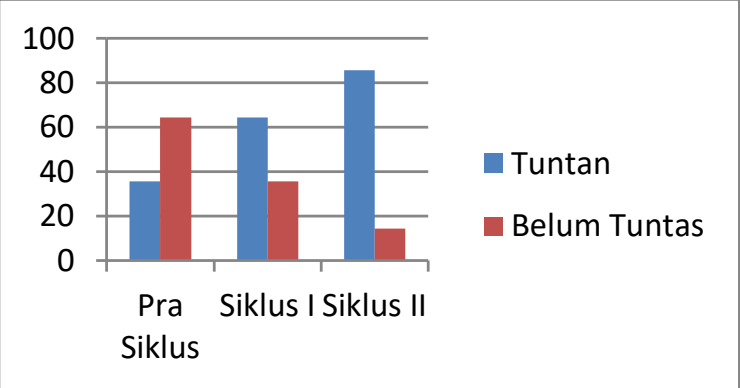

Grafik 1. Perbandingan Ketuntasa Prestasi Belajar Tema Pahlawanku Pra Siklus, Siklus I dan Siklus II

Berdasarkan Grafik 1, dapat dilihat bahwa kelengkapan siswa dan rata-rata kelas telah meningkat. Pada pra siklus pra siklus yang belum tuntas 9 orang $(64,3 \%)$, pada siklus I berkurang menjadi 5 orang (35,7\%), maka pada siklus II berkurang lagi menjadi 2 orang (14,3\%). Pada pra siklus jumlah siswa yang tuntas ada 5 orang $(35,7 \%)$, pada siklus I meningkat menjadi 9 orang $(64,3 \%)$, kemudian pada siklus II meningkat lagi menjadi 12 orang $(85,7 \%)$.

Grafik 2 rata-rata kelas pada pra siklus adalah 62, pada siklus I meningkat menjadi 71, kemudian pada siklus II ada peningkatan 8 menjadi 80. Berikut ini adalah diagram perbandingan prestasi belajar Tema Pahlawanku di pra siklus, siklus I dan siklus II.

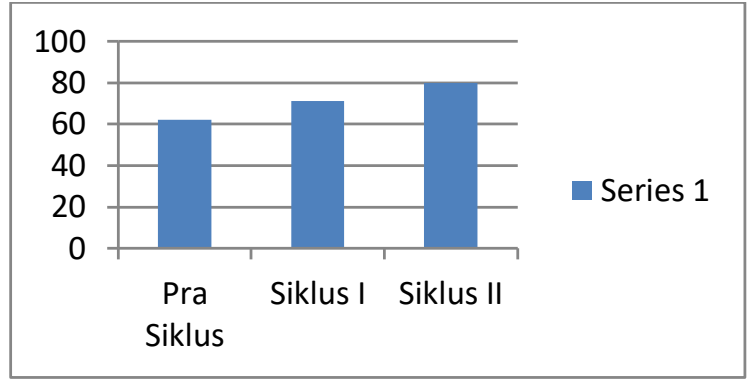

Grafik 2. Perbandingan Rata-rata Prestasi Belajar Tema Pahlawanku Pra Siklus, Siklus I dan Siklus II

\section{Pembahasan Hasil Penelitian}

Berdasarkan hasil penelitian pada siklus I ada peningkatan prestasi belajar siswa sebesar 10 (dari pra siklus dengan rata-rata 61 ke menjadi rata-rata 71). Siswa yang telah menyelesaikan atau mencapai skor KKM ditentukan 9 siswa atau setara dengan 64,3\%, sedangkan siswa yang belum menyelesaikan ada 5 orang atau sebesar 35,7\%. Pada siklus I sudah terdapat peningkatan prestasi belajar tetapi peningkatannya belum maksimal dan belum sesuai dengan indikator keberhasilan yang ditetapkan, 75\% siswa yang mengikuti proses pembelajaran telah mencapai KKM, sehingga bahwa tindakan lebih lanjut diperlukan pada siklus II.

Berdasarkan hasil penelitian pada siklus II, peningkatan prestasi belajar mencapai 19 (dari pra siklus rata-rata 61 ke siklus II menjadi ratarata 80). Siswa yang telah menyelesaikan atau mencapai skor KKM yang ditentukan adalah 12 siswa atau $85,7 \%$, sedangkan siswa 


\section{Oleh: A. Jauhar Fuad \& Ananda Dwi Permatasari}

yang belum menyelesaikan tinggal 2 atau $14,3 \%$. Pada siklus II menunjukkan peningkatan prestasi belajar yang sangat berarti dan telah sesuai dengan indikator keberhasilan $75 \%$. Siswa yang mengikuti proses pembelajaran telah mencapai KKM. Dengan demikian penelitian pada siklus II telah dianggap berhasil dan tidak dilanjutkan ke siklus berikutnya.

Berdasarkan hasil penelitian ini membuktikan bahwa pembelajaran yang menggunakan media powerpoint yang dirancang secara baik dan menarik dapat meningkatkan proses pembelajaran dan prestasi belajar siswa. Ini sejalan dengan penelitian bahwa keberhasilan pendidikan di sekolah tergantung pada apakah atau tidak desain media yang digunakan(Slameto 2003, 13). Lebih lanjut, penelitian sebelumnya menyatakan bahwa penggunaan media slide PowerPoint dapat meningkatkan aktivitas dan prestasi belajar siswa(Suryanto 2013). Kelompok eksperimen memiliki kemanjuran belajar yang lebih baik untuk belajar dengan presentasi slide PowerPoint daripada kelompok konvensional(Lai, Tsai, and Yu 2011, 43). Hasil penelitian ini menunjukkan bahwa penggunaan media Powerpoint IPA terbukti mempengaruhi minat dan prestasi belajar(Elpira and Ghufron 2015).

\section{Kesimpulan}

Berdasarkan hasil penelitian dan diskusi, dapat disimpulkan bahwa:

1. Penggunaan media powerpoint pada Tema Pahlawanku dapat meningkatkan keaktifan dan prestasi belajar siswa kelas empat SDN Sanan 1. Dilihat dari peningkatan prestasi siswa, ini membuktikan bahwa pengiriman materi ke Tema Pahlawanku menggunakan media slide PowerPoint sangat efektif untuk membantu siswa lebih memahami isi dan konsep materi. Aktivitas siswa dalam pembelajaran juga nampaknya ditandai oleh siswa tidak hanya mendengarkan penjelasan guru tetapi juga berani mengungkapkan pendapat mereka dan hasil diskusi mereka. Dalam penerapan media slide PowerPoint dalam tema Pembelajaran Pahlawanku, siswa tampak lebih antusias dan antusias dalam belajar yang berdampak pada peningkatan hasil prestasi belajar siswa pada Tema Pahlawanku.

2. Analisis hasil prestasi belajar menunjukkan bahwa nilai ratarata kelas meningkat. Pada saat 
Oleh: A. Jauhar Fuad \& Ananda Dwi Permatasari

Pra tindakan rata-rata kelas 61, setelah menjadi subjek tindakan pada siklus I nilai rata-rata kelas meningkat menjadi 71 , dan meningkat lagi pada tindakan siklus II menjadi 80. Siswa yang dapat memenuhi ketutasan belajar juga mengalami peningkatan, awalnya pada tindakan pra siklus ada 5 siswa atau sama dengan $35,7 \%$, pada tindakan siklus I menjadi 9 siswa atau sama dengan $64,3 \%$, dan meningkat lagi pada tindakan siklus II menjadi 12 siswa atau sebesar $85,7 \%$. sehingga dapat disimpulkan bahwa penggunaan media slide PowerPoint dapat meningkatkan hasil belajar siswa kelas empat SDN Sanan 1 dalam mempelajari Tema Pahlawanku.

\section{Saran}

Beberapa saran hasil penelitian ini dapat peneliti berikan kepada guru, kepalas sekolah, dan siswa:

1. Bagi guru

Pada saat pembelajaran Tema Pahlawanku guru hendaknya menggunakan media powerpoint untuk membantu memperjelas materi yang disampaikan dan guru hendaknya juga dapat menjadikan media powerpoint sebagai media alternatif untuk mata pelajaran lain sebagai upaya meningkatkan prestasi belajar siswa.

2. Bagi Kepala Sekolah

Kepada Kepala Sekolah hendaklah lebih memperhatikan kelengkapan sarana dan prasarana yang ada di sekolah agar dapat menunjang kegiatan pembelajaran serta dapat menerapkan rancanganrancangan pengajaran yangbaik dan inovatif agar pengajaran yang dilakukan dapat memberikan makna yang lebih baik bagi siswa.

3. Bagi Siswa

Siswa hendaknya lebih bersemangat dan lebih memusatkan perhatian pada saat mengikuti pembelajaran sehingga pemanfaatan media powerpoint dapat dijadikan salah satu upaya meningkatkan motivasi dan prestasi belajar siswa.

\section{Daftar Pustaka}

Apperson, Jennifer M., Eric L. Laws, and James A. Scepansky. "An Assessment of Student Preferences for PowerPoint Presentation Structure in Undergraduate Courses." Computers \& Education 50, no. 1 (January 1, 2008): 148-53. https://doi.org/10.1016/j.comp edu.2006.04.003. 
Arsyad, Azhar. Media Pembelajaran. Jakarta: PT. Raja Grafindo Persada, 2003.

Badri, Nur, and Berliana Kusuma Riasti. "Pembuatan Media Pembelajaran Interaktif Pada SMK Negeri Tiga Jepara Dengan Materi Power Point 2007." Speed - Sentra Penelitian Engineering Dan Edukasi 4, no. 1 (July 14, 2011).

http://portal.ejurnal.net/index.p hp/speed/article/view/849.

Bartsch, Robert A, and Kristi M Cobern. "Effectiveness of PowerPoint Presentations in Lectures." Computers \& Education 41, no. 1 (August 1, 2003): 77-86. https://doi.org/10.1016/S03601315(03)00027-7.

Burton, Kelley J. "Interactive Powerpoints: Is There Any Point in Giving Power to Students?" ELaw Journal 11 (December 2004).

https://eprints.qut.edu.au/1205 $2 /$.

Carmichael, Stephen W., and Wojciech Pawlina. "Animated PowerPoint as a Tool to Teach Anatomy." The Anatomical Record 261, no. 2 (April 15, 2000): 83-88. https://doi.org/10.1002/(SICI)1 097-

0185(20000415)261:2<83::AIDAR8>3.0.CO;2-D.
Djamarah, Syaiful Bahri. Psikologi Belajar. Jakarta: Rineka Cipta, 2002.

Elpira, Nira, and Anik Ghufron. "Pengaruh Penggunaan Media Powerpoint Terhadap Minat Dan Hasil Belajar IPA Siswa Kelas IV SD." Jurnal Inovasi Teknologi Pendidikan 2, no. 1 (April 30, 2015): 94-104. https://doi.org/10.21831/tp.v2i 1.5207.

Endarmoko, Eko. Tesaurus bahasa Indonesia. Jakarta: Gramedia Pustaka Utama, 2007.

Fuad, A. Jauhar. Media Dan Teknologi Pembelajaran. Kediri: IAIT, 2010.

Fuad, A. Jauhar, and Hamam. Teori Dan Praktik Penelitian Tindakan Kelas (PTK). Tulungagung: STAIN Tulungagung, 2012.

Fuad, A. Jauhar, and Manu Winarsih. "Peningkatan Prestasi Belajar Dengan Metode Bermain Peran Pada Tema Kegiatan Jual Beli." Ed-Humanistics: Jurnal Ilmu Pendidikan 3, no. 1 (April 25, 2018).

http://ejournal.unhasy.ac.id/ind ex.php/edhumanistics/article/view/251.

Holzl, J. "Twelve Tips for Effective PowerPoint Presentations for the Technologically Challenged." Medical Teacher 19, no. 3 (January 1, 1997): 175-79. https://doi.org/10.3109/01421 599709019377. 
Pemanfaatan Media Slide Power Point dalam Meningkatkan Prestasi Siswa...

Oleh: A. Jauhar Fuad \& Ananda Dwi Permatasari

Kristiantari, Mg Rini. "Analisis Kesiapan Guru Sekolah Dasar Dalam Mengimplementasikan Pembelajaran Tematik Integratif Menyongsong Kurikulum 2013." JPI (Jurnal Pendidikan Indonesia) 3, no. 2 (January 5, 2015). https://doi.org/10.23887/jpiundiksha.v3i2.4462.

Lai, Yen-Shou, Hung-Hsu Tsai, and $\mathrm{Pao}-\mathrm{Ta} \quad \mathrm{Yu}$. "Integrating Annotations into a Dual-Slide PowerPoint Presentation for Classroom Learning." Journal of Educational Technology \& Society 14, no. 2 (2011): 43-57.

Levasseur, David G., and J. Kanan Sawyer. "Pedagogy Meets PowerPoint: A Research Review of the Effects of ComputerGenerated Slides in the Classroom." The Review of Communication, August 19, 2006. https://doi.org/10.1080/15358 590600763383.

Mulyani, Dessy. "Hubungan Kesiapan Belajar Siswa Dengan Prestasi Belajar." Konselor 2, no. 1 (January 1, 2013). https://doi.org/10.24036/0201 321729-0-00.

Murtikusuma, Randi Pratama. "Pengembangan Perangkat Pembelajaran Matematika Model Problem-Based Learning Berbantuan Media Powerpoint Untuk Siswa Kelas XI SMK Materi Barisan Dan Deret." Saintifika 17, no. (2015). https://jurnal.unej.ac.id/index.p $\mathrm{hp} / \mathrm{STF} /$ article/view/2733.

Nurhidayat, Oki. "Perbandingan Media Power Point Dengan Flip Chart Dalam Meningkatkan Pengetahuankesehatan Gigi Dan Mulut." Unnes Journal of Public Health 1, no. 1 (2012). https://doi.org/10.15294/ujph.v 1i1.179.

Nurlatifah,

"Pengembangan Media

Pembelajaran Ipa Berbasis Microsoft Office Power Point Interaktif Pada Siswa Kelas IV SD Negeri Ngrukeman Kasihan Bantul." Jurnal PGSD Indonesia 1, no. 2 (January 8, 2015). http://ojs.upy.ac.id/ojs/index.ph p/JPGSDI/article/view/299.

Penciner, Rick. "Does PowerPoint Enhance Learning?" Canadian Journal of Emergency Medicine 15, no. 2 (March 2013): 109-12. https://doi.org/10.2310/8000.2 013.130756.

Prastowo, Andi. Menyusun Rencana Pelaksanaan Pembelajaran (RPP) Tematik Terpadu. Jakarta: Kencana, 2017. https://books.google.com/books /about/Menyusun_Rencana_Pela ksanaan_Pembelajara.html?id=_J BBDwAAQBAJ.

Siagian, Roida Eva Flora. "Pengaruh Minat Dan Kebiasaan Belajar Siswa Terrhadap Prestasi Belajar Matematika." Formatif: Jurnal Ilmiah Pendidikan MIPA 2, no. 2 
Pemanfaatan Media Slide Power Point dalam Meningkatkan Prestasi Siswa...

Oleh: A. Jauhar Fuad \& Ananda Dwi Permatasari

(August 5, 2015).

https://doi.org/10.30998/forma tif.v2i2.93.

Slameto. Belajar Dan Faktor-Faktor Yang Mempengaruhinya. Jakarta: Rineka Cipta, 2003.

Stein, Karen. "The Dos and Don'ts of PowerPoint Presentations." Journal of the American Dietetic Association 106, no. 11 (November 1, 2006): 1745-48. https://doi.org/10.1016/j.jada.2 006.09.029.

Sudjana, Nana, and Ahmad Rivai. Media Pengajaran. Bandung: Sinar Baru Algensindo, 2009.

Sukarsa, I. Wayan, Nyoman Dantes, and Ni Wayan Arini. "Penerapan Model Pembelajaran Kuantum Berbantuan Media Microsoft Powerpoint Untuk Meningkatkan Aktivitas Dan Hasil Belajar Ipa Siswa Kelas IV Semester 1 SD Negeri 6 Menanga." MIMBAR PGSD Undiksha 2, no. 1 (March 3, 2014).

https://ejournal.undiksha.ac.id/i ndex.php/JJPGSD/article/view/ 2555.

Sungkono, Sungkono. "Pembelajaran Tematik Dan Implementasinya Di Sekolah Dasar." Majalah Ilmiah Pembelajaran 2, no. 1 (May 10, 2006).

https://journal.uny.ac.id/index.p hp/mip/article/view/7113.

Suryanto, Mardian. Penggunaan Power Point Untuk Meningkatkan
Aktivitas Dan Hasil Belajar Pada Pembelajaran IPS. Lampung: Fakultas Keguruan dan Ilmu Pendidikan, 2013.

Utari, Unga, I. Nyoman Sudana Degeng, and Sa'dun Akbar. "Pembelajaran Tematik Berbasis Kearifan Lokal Di Sekolah Dasar Dalam Menghadapi Masyarakat Ekonomi Asean (MEA)." Jurnal Teori Dan Praksis Pembelajaran IPS 1, no. 1 (April 30, 2016): 3944.

https://doi.org/10.17977/jtp2ip s.v1i1.5861.

Wangid, Muhammad Nur, Ali Mustadi, Vera Yuli Erviana, and Slamet Arifin. "Kesiapan Guru SD dalam

Pelaksanaan

Pembelajaran Tematik-Integratif Pada Kurikulum 2013 di DIY." Jurnal Prima Edukasia 2, no. 2 (July 1, 2014): 175-82. https://doi.org/10.21831/jpe.v2 i2.2717. 